\title{
Combined Industrial Wastewater Treatment in Anaerobic Bioreactor Posttreated in Constructed Wetland
}

\author{
Bibi Saima Zeb, ${ }^{1}$ Qaisar Mahmood, ${ }^{1}$ Saima Jadoon, ${ }^{2}$ Arshid Pervez, ${ }^{1}$ Muhammad Irshad, ${ }^{1}$ \\ Muhammad Bilal, ${ }^{1}$ and Zulfiqar Ahmad Bhatti ${ }^{1}$ \\ ${ }^{1}$ Department of Environmental Sciences, COMSATS Institute of Information Technology, Abbottabad 22060, Pakistan \\ ${ }^{2}$ Department of Natural Resources Engineering and Management, University of Kurdistan, Hewler, Iraq
}

Correspondence should be addressed to Qaisar Mahmood; mahmoodzju@gmail.com

Received 17 October 2013; Accepted 13 November 2013

Academic Editor: Chong-Jian Tang

Copyright (c) 2013 Bibi Saima Zeb et al. This is an open access article distributed under the Creative Commons Attribution License, which permits unrestricted use, distribution, and reproduction in any medium, provided the original work is properly cited.

\begin{abstract}
Constructed wetland (CW) with monoculture of Arundo donax L. was investigated for the posttreatment of anaerobic bioreactor (ABR) treating combined industrial wastewater. Different dilutions of combined industrial wastewater $(20,40,60$, and 80$)$ and original wastewater were fed into the $\mathrm{ABR}$ and then posttreated by the laboratory scale CW. The respective removal efficiencies of COD, BOD, TSS, nitrates, and ammonia were $80 \%, 78-82 \%, 91.7 \%, 88-92 \%$, and $100 \%$ for original industrial wastewater treated in $\mathrm{ABR}$. ABR was efficient in the removal of $\mathrm{Ni}, \mathrm{Pb}$, and $\mathrm{Cd}$ with removal efficiencies in the order of $\mathrm{Cd}(2.7 \%)>\mathrm{Ni}(79 \%)>\mathrm{Pb}(85 \%)$. Posttreatment of the ABR treated effluent was carried out in lab scale CW containing A. donax $\mathrm{L}$. CW was effective in the removal of COD and various heavy metals present in ABR effluents. The posttreatment in CW resulted in reducing the metal concentrations to $1.95 \mathrm{mg} / \mathrm{L}, 0 \mathrm{mg} / \mathrm{L}$, and $0.004 \mathrm{mg} / \mathrm{L}$ for $\mathrm{Ni}, \mathrm{Pb}$, and $\mathrm{Cd}$ which were within the permissible water quality standards for industrial effluents. The treatment strategy was effective and sustainable for the treatment of combined industrial wastewater.
\end{abstract}

\section{Introduction}

Pakistan's current population of 180 million is expected to grow to about 221 million by the end of year 2025 [1]. In Pakistan and other developing countries, water pollution is a major threat to the livelihood of people [2]. The heavy metals contamination of aquatic and terrestrial ecosystems is a major environmental problem. Each pollution problem calls for specific optimal and cost-effective solution; if one technology proves less or ineffective, the other takes its place. It is indispensable to treat industrial wastewaters for their subsequent use for irrigation, drinking, and other purposes. In addition, due to an increased scarcity of clean water, there is a need for appropriate management of available water resources [3]. The factors like profound demographic, economic changes and global energy crisis are compelling the implementation of low-cost natural treatment systems for the domestic and industrial wastewaters [1].

In the recent years, the wastewater treatment strategies have been shifted to one of the most promising methods, that is, biological anaerobic treatment with the adoption of high rate anaerobic systems like upflow anaerobic sludge blanket (UASB) and other related treatment systems. The outstanding characteristics of high rate ABR include the anaerobic microorganisms capable of aggregation, low operational and maintenance costs, energy recovery in the form of biogas, low energy consumption, and low production of digested sludge [4-7]. In developing countries like India, Brazil, and Colombia, where financial resources are generally scarce due to high energy costs, the process is familiar as one of the most feasible methods for the wastewater treatment. Despite several modifications, the quality of ABR treated effluent hardly ever meets the discharge standards [6, 8]. Lettinga and coresearchers applied ABR process for municipal wastewater treatment since early 1980 [9-13] and reported that about 70\% of chemical oxygen demand (COD) removal can be achieved under warm climates $[6,14,15]$. Since its inception, wider hype has been gained by this process $[16,17]$. The ABR treated effluents can be employed for irrigation of various crops. However, such type of effluent may be high in chemical oxygen demand (COD), biochemical oxygen demand (BOD), and coliforms [18]. Thus, additional posttreatment strategy 
is mandatory for the ABR treated effluents if further use is desired [19-21].

CW wastewater treatment systems are engineered structures specifically designed for treating wastewater by optimizing the physical, chemical, and biological processes that occur in natural wetland ecosystems [1, 18, 22-24]. CW is known as green technology which uses plants for the removal of contaminants from a specified area, and process is known as phytoremediation [25]. CW is a low-cost or economical on-site wastewater treatment technology which is not only effective but also aesthetically pleasing. Since 1980 the utilization of the $\mathrm{CW}$ for the treatment of variety of wastewater has quickly become widespread. The amount of nutrients removed by plants and stored in their tissues is highly relative which depends on the plant type, biomass, and nutrient concentration in tissues [26].

The plant species, media like sand and gravel of specific ratio and size, and containers are the foundation materials for CW. There are two major types of CW, subsurface flowing water (SSF) CW and free water surface (FWS) flowing CW. A variety of macrophytes are used in CW and most common are floating macrophytes (i.e., Lemna spp. or Eichhornia crassipes), submerged macrophytes (i.e., Elodea canadensis), and rooted emergent macrophytes (i.e., Phragmites australis and Typha angustifolia). The plants roots create conducive environment for the microbial growth and in winter the plant litter acts as insulator. CW is attached growth biological reactors, which tender higher pollutant removal efficiency through physical, chemical, and biological mechanisms. The common removal mechanisms associated with wetlands include sedimentation, coagulation, adsorption, filtration, biological uptake, and microbial transformation [3, 24, 27].

CW technology is well known at present, but it is not well documented for treating specific industrial effluents [28-30]. A variety of posttreatment configurations based on various combinations with ABR have been studied; ABR followed by final polishing units (FPU) or polishing pond (PP) is a common process used in India, Colombia, and Brazil due to its simplicity in operation $[6,31-33]$. The implementation of low-cost, simple mitigation measures is required for the timely control and sustainable management of pollution problems in developing countries. The objective of this study was to evaluate the performance of $\mathrm{ABR}$ for the treatment of combined industrial wastewater followed by posttreatment in CW planted with $A$. donax.

\section{Materials and Methods}

2.1. Collection of Wastewater and Treatment. The industrial wastewater was collected from combined drain at Hattar Industrial Estate, Hattar, Pakistan, as grab samples. The physicochemical parameters like $\mathrm{pH}$, turbidity, and EC were determined onsite while the rest were analyzed in the laboratory within $24 \mathrm{~h}$. As a treatment strategy and to avoid toxic effects of the pollutants, various dilutions of wastewater included $20,40,60$, and $80 \%$ to feed into ABR, after which original wastewater was also treated in $\mathrm{ABR}$ and then $\mathrm{CW}$.

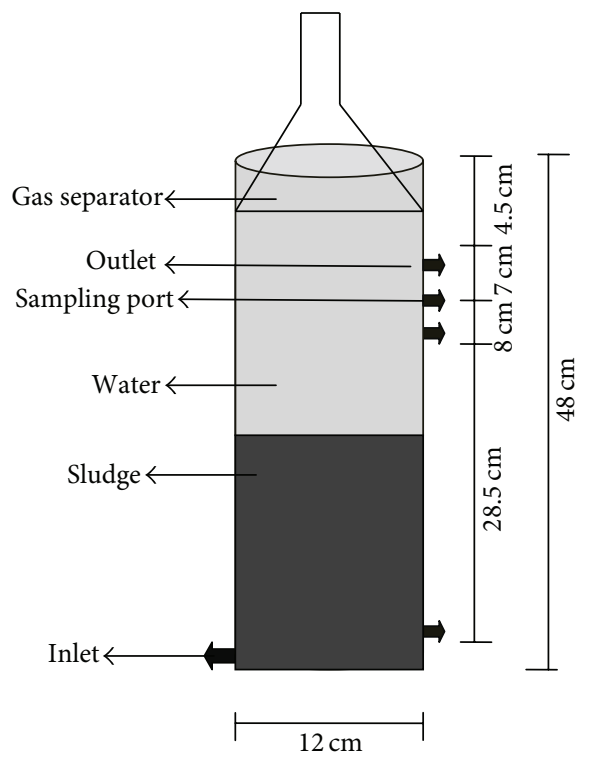

FIGURE 1: Schematic diagram of a lab scale anaerobic bioreactor with its dimensions.

2.2. ABR Experimental Setup. This research work was carried out in the bioremediation laboratory of COMSATS Institute of Information Technology, Abbottabad, Pakistan. In this study ABR was used as a primary treatment step. A lab scale ABR was operated in upflow mode with biomass retention as shown in Figure 1. The reactor is made of Perspex with a working volume of 5 liters. The influent was pumped into ABR using peristaltic pump from the influent vessel to the reactor (Figure 1). The flow rate was adjusted according to results of startup study. A recycling pump was used to mix the influent (substrate) and sludge (biocatalyst) and to decrease possible substrate inhibition. The ratio of recycle flow to the influent flow was set at about 2.5-3. Bioreactor startup was carried out by feeding synthetic wastewater and nutrient solution at various organic loading rate (OLR) and COD by using organic compounds, at a fixed Hydraulic retention time (HRT) but increasing OLR and at fixed OLR but decreasing HRT.

Industrial wastewater samples were collected from Hattar Industrial Estate (Haripur, Pakistan) after characterization and were fed into the ABR. Different dilutions of real industrial wastewater were made to avoid the reactor disturbances before feeding to ABR.

2.3. Experimental Setup. The lab scale experimental constructed wetland consists of two independent rectangular basins (length: $120 \mathrm{~cm}$, width: $90 \mathrm{~cm}$, and depth: $40 \mathrm{~cm}$ ). The basins were filled with gravel, sand, and soil from bottom to top with one layer of each as shown in Figure 2. Each basin had a $10 \%$ slope and was equipped with a nozzle outlet for discharging the treated effluent. The $\mathrm{CW}$ was planted with $A$. donax $\left(6\right.$ shoots $\left./ \mathrm{m}^{2}\right)$ taken from the botanical garden of the institute.

An unplanted bed served as a control. Treated effluents were collected directly from the lab scale experimental plant 


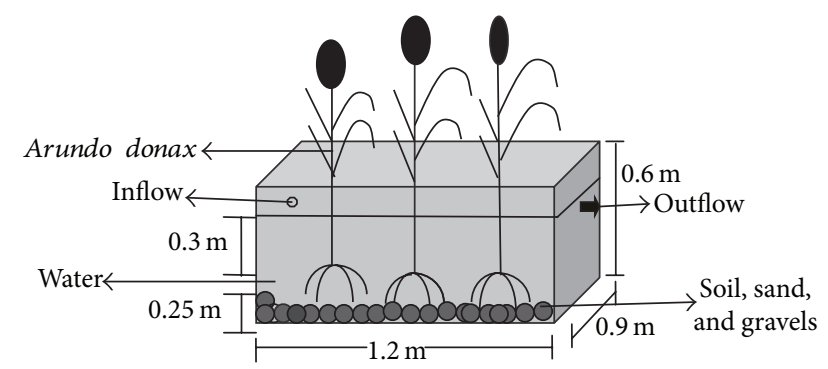

FIGURE 2: Schematic diagram of a laboratory scale CW for the treatment of combined industrial wastewater.

TABLE 1: Dimensions and operating conditions of experimental CW.

\begin{tabular}{lc}
\hline Dimensions of CW & \\
Length & $1.2 \mathrm{~m}$ \\
Width & $0.9 \mathrm{~m}$ \\
Total height & $0.6 \mathrm{~m}$ \\
Total container volume & $0.432 \mathrm{~m}^{3}$ \\
Water depth & $0.3 \mathrm{~m}$ \\
Substrate depth & $0.25 \mathrm{~m}$ \\
Plant name & Arundo donax L. (giant reed) \\
No. of rhizome/m & 3 \\
Operating conditions & \\
OLR & $538 \mathrm{~kg} / \mathrm{ha} / \mathrm{d}$ \\
HRT & $3 \mathrm{days}$ \\
HLR & $862 \mathrm{~m}^{3} / \mathrm{ha} / \mathrm{d}$ \\
\hline
\end{tabular}

of the wastewater treatment laboratory. The operational conditions of the experimental setup of CW are shown in Table 1. All plants, sand, and gravel were properly washed before planting to CW system.

Pollutant removal rates (\%) were calculated according to the following equation:

$$
R(\%)=\left[1-\left(\frac{C f}{C i}\right)\right] \times 100,
$$

where $R$ is the removal rate, $C i$ is the concentration $(\mathrm{mg} / \mathrm{L})$ of the considered parameter in the untreated WW (influent), and $C f$ is the concentration $(\mathrm{mg} / \mathrm{L})$ of the considered parameter in the treatment bed effluent.

2.4. Analytical Procedures. Raw and treated samples were analyzed for their BOD, COD, EC, $\mathrm{pH}$, turbidity, and so forth, according to the standard methods [34]. For COD determination closed reflux, calorimetric method included digestion at $150^{\circ} \mathrm{C}$ for $2 \mathrm{~h}$ in COD vials followed by spectrophotometer reading at $530 \mathrm{~nm}$ [34]. The $\mathrm{pH}$ was measured using a digital pH meter (HANNA, HI 991003 Sensor Check pH) and TDS and conductivity by HANNA, HI9835 Microprocessor for conductivity and TDS. Heavy metals were analyzed through atomic absorption spectrophotometer. At least three readings were taken for each parameter each time and then mean value was calculated.
2.5. Statistical Analysis. Collected data were analyzed by the descriptive statistics and arithmetic averages of percent removal were calculated using Microsoft Excel XP version 2010 and Origin Lab 8.

\section{Results and Discussion}

3.1. Characterization of Combined Industrial Wastewater. Physicochemical characteristics of industrial wastewater were depicted in Table 2. Four different dilutions (20\%, 40\%, $60 \%$, and $80 \%$ ) and original WW from HIE had the following characteristics.

3.2. Pretreatment of Combined Industrial Wastewater in $A B R$. The ABR was fed with combined industrial wastewater for treatment at retention time of $12 \mathrm{~h}$. The treated effluent characteristics and percent removal efficiency was showed in Table 3.

The results described the performance of the ABR for the treatment of combined industrial wastewater, as the concentrations of COD before pretreatment were 70, 189, 284, 379 , and $474 \mathrm{mg} / \mathrm{L}$, respectively, for four different dilutions of $20,40,60$, and 80 and original wastewater. After pretreatment with ABR the COD was reduced to $42,54,121,159$, and $297 \mathrm{mg} / \mathrm{L}$ with 40.0, 40.8, 57.3, 58.0, and 37.3\% removal efficiency, respectively. The results in Figure 3 showed the maximum COD removal efficiency for the $80 \%$ dilution of the wastewater through $\mathrm{ABR}$. The $\mathrm{ABR}$ also reduced the BOD concentrations of the dilutions from 78 to $82 \%$ as shown in Figure 3. The BOD concentration reduced from $23.3,25.4,50.9,77.0$ and $84.8 \mathrm{mg} / \mathrm{L}$ to $18.5,4.16,5.1,10.2$, and 18.5 , respectively. It was observed from the results that $A B R$ showed excellent removal efficiency for BOD removal.

Total solids were tremendously removed by $91.7 \%$ with the corresponding concentration of $1400 \mathrm{mg} / \mathrm{L}$ for original wastewater. The concentration of $\mathrm{NO}_{3}-\mathrm{N}$ was reduced from $24,59,83,98$, and 145 to $1.8,6.1,9.23,8.9$, and $16 \mathrm{mg} / \mathrm{L}$ for $20,40,60$, and 80 and original wastewater. ABR showed 88 to $92 \%$ removal efficiency for the $\mathrm{NO}_{3}$-nitrogen as shown in Figure 4.

Similarly, the removal efficiency of $\mathrm{NH}_{4}-\mathrm{N}$ was $87.6,90.8$, $90,85.9$, and $87.8 \%$ for the four different dilutions 20,40 , 60 , and 80 and original wastewater, respectively, as shown

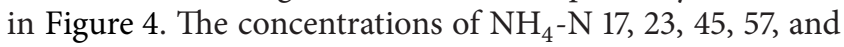
$82 \mathrm{mg} / \mathrm{L}$ were reduced to $2.1,2.1,4.5,8$, and $10 \mathrm{mg} / \mathrm{L}$. On the other hand, $\mathrm{Pb}, \mathrm{Ni}$, and $\mathrm{Cd}$ removal by reactor was $2.7 \%$, $79 \%$, and $85 \%$ for real industrial wastewater. The heavy metals removal were found in order $\mathrm{Cd}>\mathrm{Ni}>\mathrm{Pb}$ shown in Figure 5.

The previous workers observed that the treatment of complex industrial wastewater reduced the efficiency of the ABR as in the present study [35]. During anaerobic digestion processes of organic matter the biochemical reaction takes place which is affected by the heavy metals presence [35]. It is clear from the results that soluble heavy metals rapidly decreased at the initial concentrations. It depends on which chemical form the heavy metal is existed. The most common and important form of the heavy metals are precipitation (as sulfides, carbonates, and hydrocarbons) and sorption on to 
TABLE 2: Characterization of four different dilutions and original WW of combined industrial wastewater.

\begin{tabular}{|c|c|c|c|c|c|}
\hline \multirow{2}{*}{ Parameters } & \multicolumn{5}{|c|}{ Influent/raw wastewater dilutions } \\
\hline & $20 \%$ & $40 \%$ & $60 \%$ & $80 \%$ & Original WW \\
\hline $\mathrm{pH}$ & 8.1 & 8.48 & 8.6 & 8.76 & 10.2 \\
\hline Conductivity $(\mu \mathrm{s})$ & 627 & 646 & 645 & 676 & 702 \\
\hline TDS & 378 & 330 & 344 & 394 & 411 \\
\hline TS & 712 & 812 & 780 & 1333 & 1400 \\
\hline VS & 600 & 520 & 1050 & 1160 & 1960 \\
\hline COD & 70 & 189 & 284 & 379 & 474 \\
\hline BOD & 23.3 & 25.4 & 50.9 & 77 & 84.8 \\
\hline Nitrates & 24 & 59 & 83 & 98 & 145 \\
\hline Ammonia & 17 & 23 & 45 & 57 & 82 \\
\hline Lead & 0.131 & 0.653 & 1.335 & 1.851 & 2.337 \\
\hline Nickel & 0.117 & 0.225 & 0.315 & 0.271 & 0.403 \\
\hline Cadmium & 0.026 & 0.021 & 0.009 & 0.026 & 0.048 \\
\hline
\end{tabular}

The values are given as $\mathrm{mg} / \mathrm{L}$ except $\mathrm{pH}$ and conductivity.

TABLE 3: The performance of ABR in treating combined industrial effluents.

\begin{tabular}{|c|c|c|c|c|c|c|c|c|c|c|c|c|c|c|c|}
\hline \multirow{2}{*}{ Parameters } & \multicolumn{5}{|c|}{ Influent/raw wastewater } & \multicolumn{5}{|c|}{ ABR effluent } & \multicolumn{5}{|c|}{$\%$ removal } \\
\hline & $20 \%$ & $40 \%$ & $60 \%$ & $80 \%$ & Original WW & $20 \%$ & $40 \%$ & $60 \%$ & $80 \%$ & Original WW & $20 \%$ & $40 \%$ & $60 \%$ & $80 \%$ & Original WW \\
\hline $\mathrm{pH}$ & 8.1 & 8.48 & 8.6 & 8.76 & 10.2 & 7.89 & 8.31 & 8.52 & 8.66 & 8.41 & - & - & - & - & - \\
\hline Conductivity $(\mu \mathrm{s})$ & 627 & 646 & 645 & 676 & 702 & 654 & 616 & 645 & 687 & 702 & - & - & - & - & - \\
\hline TDS & 378 & 330 & 344 & 394 & 411 & 339 & 324 & 334 & 357 & 365 & 10 & 2 & 3 & 9 & 11 \\
\hline TS & 712 & 812 & 780 & 1333 & 1400 & 83 & 85 & 93 & 215 & 115 & 88 & 89.5 & 88 & 83.8 & 91.7 \\
\hline VS & 600 & 520 & 1050 & 1160 & 1960 & 45 & 86.3 & 163.9 & 97.2 & 305 & 92 & 83.5 & 86 & 90 & 84 \\
\hline COD & 70 & 189 & 284 & 379 & 474 & 42 & 54 & 121 & 159 & 297 & 40 & 47.8 & 57.3 & 58.04 & 37.34 \\
\hline BOD & 23.3 & 25.4 & 50.9 & 77 & 84.8 & 18.5 & 4.16 & 5.1 & 10.2 & 18.5 & 82 & 80 & 80 & 81 & 78 \\
\hline Nitrates & 24 & 59 & 83 & 98 & 145 & 1.8 & 6.1 & 9.23 & 8.9 & 16 & 92.5 & 89.6 & 88.8 & 90.9 & 88.9 \\
\hline Ammonia & 17 & 23 & 45 & 57 & 82 & 2.1 & 2.1 & 4.5 & 8 & 10 & 87.6 & 90.8 & 90 & 85.9 & 87.8 \\
\hline Lead & 0.131 & 0.653 & 1.335 & 1.851 & 2.337 & 0.558 & 0.653 & 1.222 & 2.109 & 2.703 & 64 & 27.8 & 8.46 & 7.4 & 2.7 \\
\hline Nickle & 0.117 & 0.225 & 0.315 & 0.271 & 0.403 & 0.079 & 0.015 & 0.035 & 0.074 & 1.014 & 92.1 & 93.4 & 87 & 79 & 79 \\
\hline Cadmium & 0.026 & 0.021 & 0.009 & 0.026 & 0.048 & 0.009 & 0.008 & 0.001 & 0.009 & 0.007 & 65.4 & 62 & 88.9 & 96.2 & 85.4 \\
\hline
\end{tabular}

The values are given as $\mathrm{mg} / \mathrm{L}$ except $\mathrm{pH}$ and conductivity.

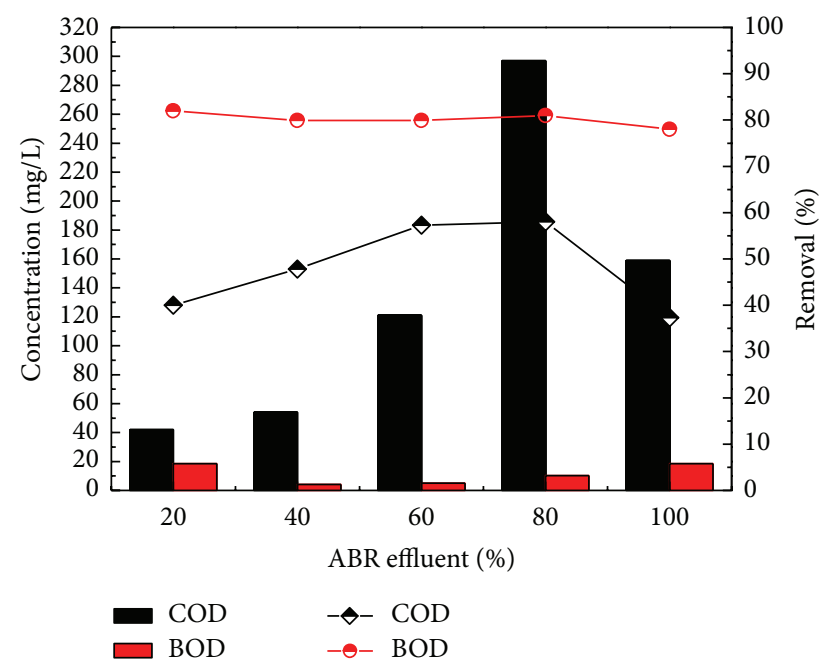

Figure 3: COD removal efficiency of a lab scale ABR reactor for combined industrial wastewater.

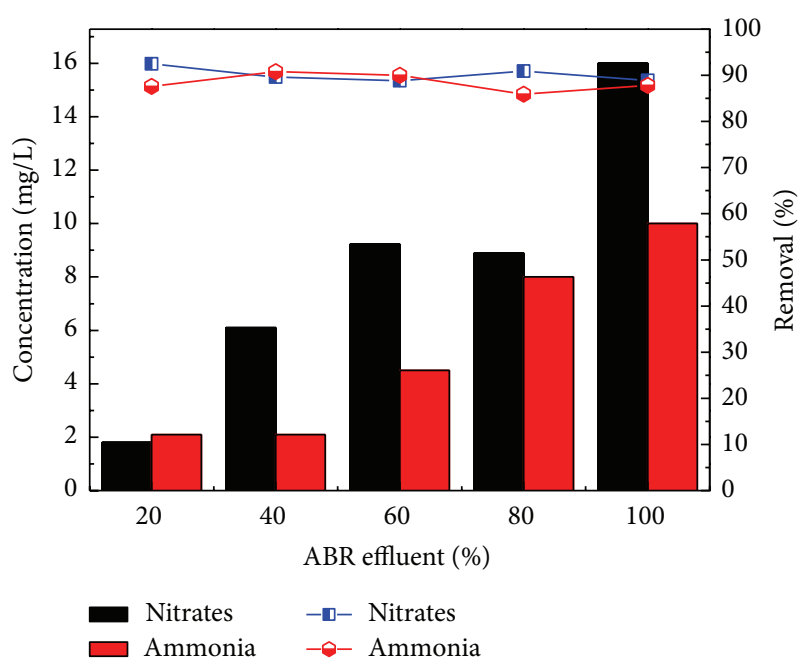

FIGURE 4: Nitrates Removal efficiency of pretreatment of combined industrial wastewater with $\mathrm{ABR}$. 


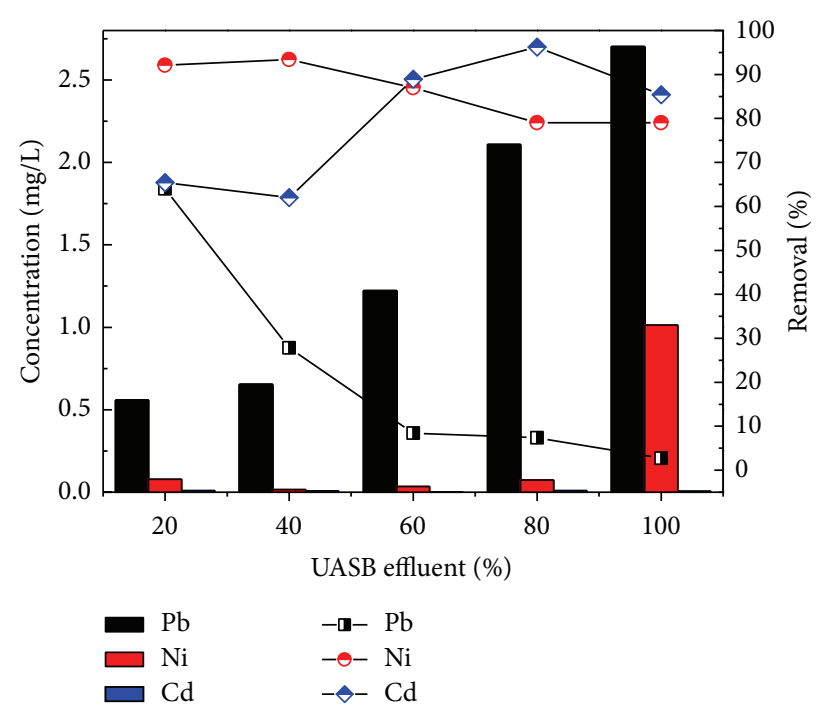

Figure 5: Removal efficiency of $\mathrm{Pb}, \mathrm{Ni}$, and $\mathrm{Cd}$ by ABR.

solid form (Inhibition effect of heavy metals on anaerobic sludge) [36]. Ni could be bound in all forms. So it was cleared that high initial concentrations were tolerated by the ABR sludge and thus showed the satisfactory removal of the heavy metals.

However, the residual concentration of organic (BOD and COD) and heavy metals in the anaerobic reactor effluent usually exceeds the maximum permissible level prescribed by the effluent discharge standards of most developing countries $[20,37,38]$. From this standpoint, posttreatment of anaerobic effluent is necessary to reduce these contaminants to the required level [39].

3.3. Posttreatment of ABR Effluent with Constructed Wetland. The pretreated effluent was then further treated by $\mathrm{CW}$ at HRT of 3 days for each dilution. The results for FWS CW effluent are shown in Figures 6, 7, 8, 9, and 10 with pollutant percent removal efficiency.

The results of treatment in CW showed efficient removal efficiency for COD, BOD, TS, nitrates, ammonia, and heavy metals like $\mathrm{Pb}, \mathrm{Ni}$, and $\mathrm{Cd}$. The residual concentration of COD and BOD was $64.3,66.7,67,76.4$, and 82.4 and 78.4, 76, $80.3,80.3$, and $78.4 \mathrm{mg} / \mathrm{L}$, respectively, for the corresponding dilutions of 20,40,60, and 80 and original WW as shown in Figures 6 and 7. The CW showed the highest COD removal efficiency of $82.4 \%$ for original WW, but at the same dilution the BOD was reduced to $78.4 \%$. Nitrates and ammonia removal efficiency was found to be $95,82,86,72$, and $75 \%$ for the respective concentrations of $1.8,6.1,9.23,8.9$, and $16 \mathrm{mg} / \mathrm{L}$ of the corresponding four different dilutions and original pretreated effluent. Ammonia removal was not satisfactory as compared to other parameters and the highest removal efficiency was $70.1 \%$ by CW.

CW normally improves the DO in wetland. The introduction of excess organic matter may result in a depletion of oxygen from an aquatic system. Prolonged exposure to low

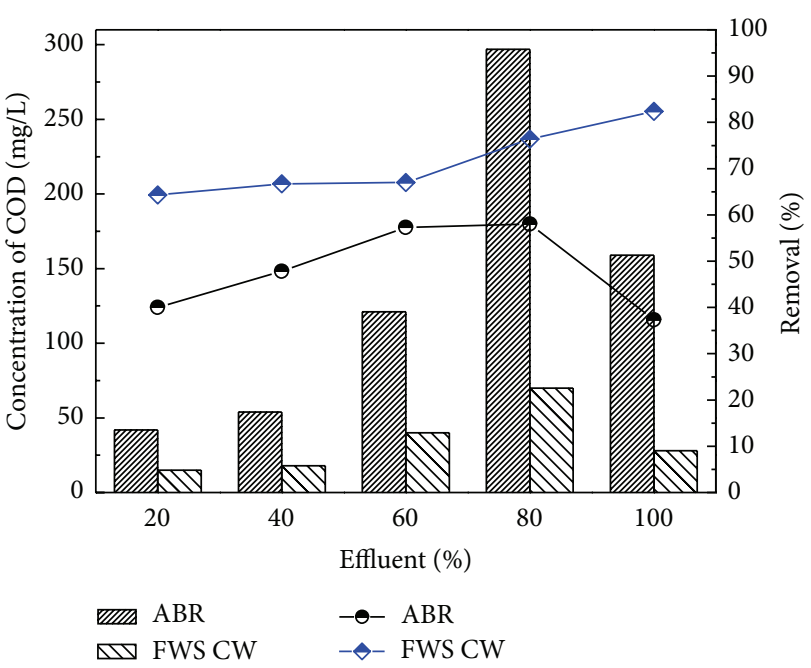

FIgURE 6: Comparison of ABR and CW for COD removal.

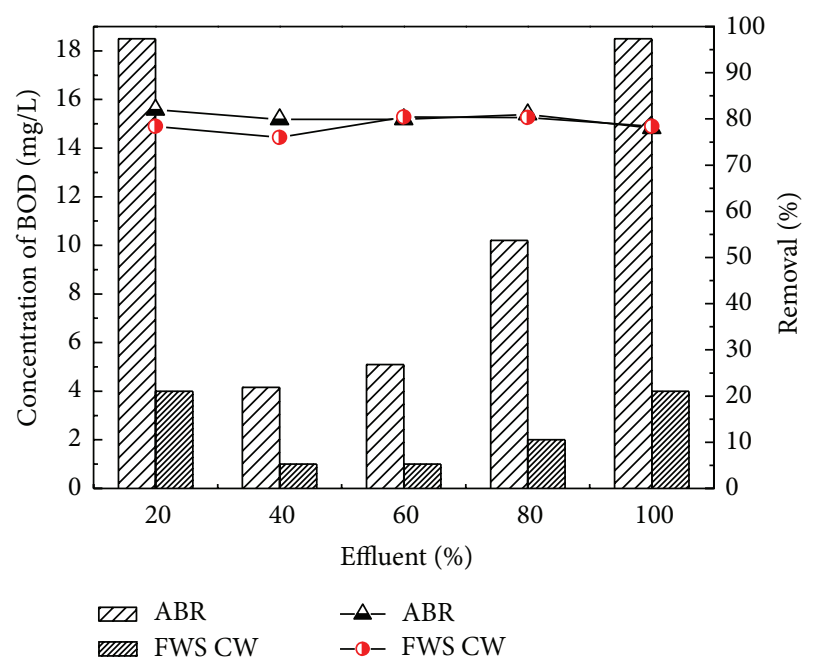

FIGURE 7: Comparison of ABR and CW for BOD removal.

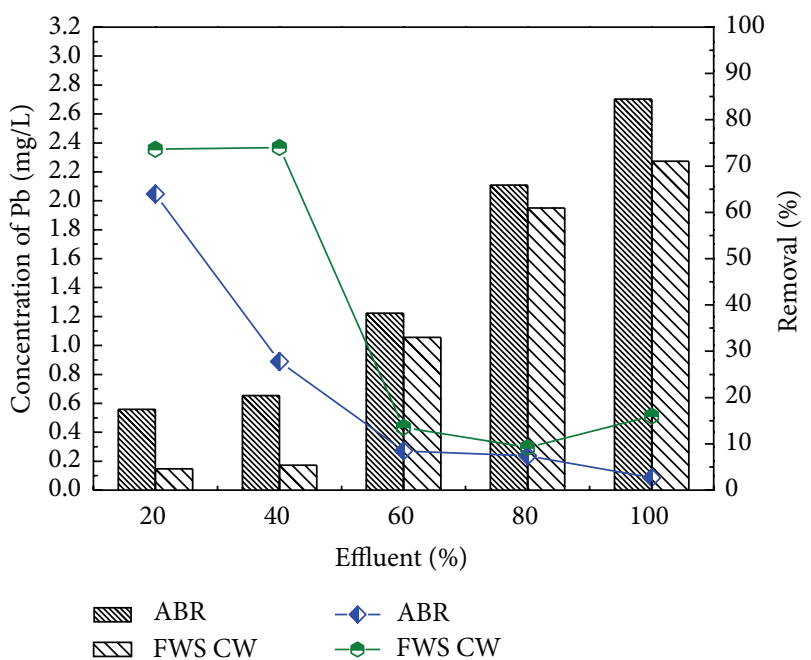

FIGURE 8: Comparison of \% removal efficiency of $\mathrm{Pb}$ in $\mathrm{ABR}$ and FWS CW. 


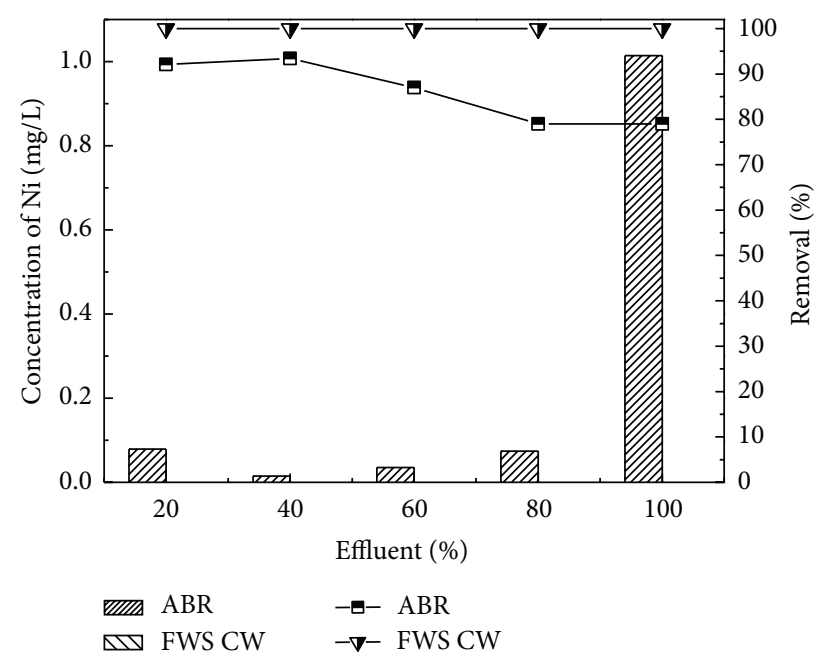

Figure 9: Comparison of percent removal efficiency of $\mathrm{Ni}$ in ABR and FWS SCW.

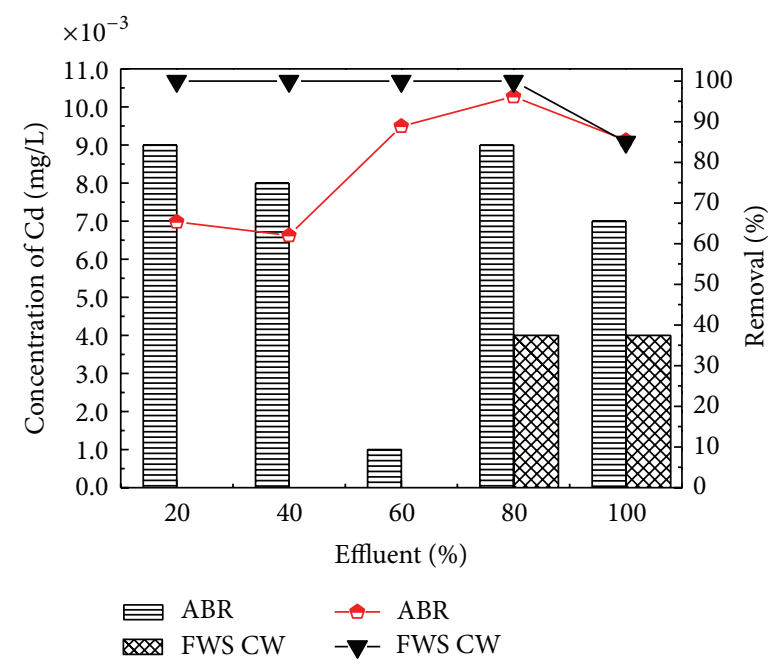

FIGURE 10: Comparison of \% removal efficiency of Cd in ABR and FWS CW.

dissolved oxygen levels $(<5.0-6.0 \mathrm{mg} / \mathrm{L})$ may not directly kill an organism but will increase its susceptibility to other environmental stresses. Exposure to $<30 \%$ saturation $(<2.0 \mathrm{mg} / \mathrm{L}$ oxygen) for one to four days kills most of the biota in a system. If oxygen-requiring organisms perish, the remaining organisms will be air-breathing insects and anaerobic (not requiring oxygen) bacteria [40]. If all oxygen is depleted, aerobic (oxygen-consuming) decomposition ceases. So, treating pollutants in wetlands may help to increase DO which is consumed by the other aerobes. In this experiment during the posttreatment by CW the DO increased up to $8.8 \mathrm{mg} / \mathrm{L}$.

Industrial wastewater was treated in two-stage constructed wetland [41] planted with Typha latifolia and Phragmites australis. For tannery wastewater, CW may be an interesting treatment option. Two-stage series of horizontal subsurface flow CW with Phragmites australis (UP series) and Typha latifolia (UT series) provided high removal of organics from tannery wastewater, up to $88 \%$ of biochemical oxygen demand $\left(\mathrm{BOD}_{(5)}\right)$ (from an inlet of 420 to $1000 \mathrm{mg} / \mathrm{L}$ ) and $92 \%$ of chemical oxygen demand (COD) (from an inlet of 808 to $2449 \mathrm{mg} / \mathrm{L}$ ) and of other contaminants, such as nitrogen, operating at hydraulic retention times of 2, 5, and 7 days. Overall mass removals of up to $1294 \mathrm{~kg} \mathrm{COD} / \mathrm{ha} / \mathrm{d}$ and $529 \mathrm{~kg}$ $\mathrm{BOD}_{(5)} / \mathrm{ha} / \mathrm{d}$ were achieved for a loading ranging from 242 to $1925 \mathrm{~kg}$ COD ha/d and from 126 to $900 \mathrm{~kg} \mathrm{BOD}(5) / \mathrm{ha} / \mathrm{d}$. Plants were resilient to the conditions imposed; however $P$. australis exceeded T. latifolia in terms of propagation. In the present study, $A$. donax was used in the CW for post treatment which showed the efficient performance for the further removal of pollutants from the ABR pretreated effluent. The results confirmed that effluent showed traces of heavy metals $\mathrm{Ni}$ and $\mathrm{Cd}$ with the corresponding ABR treated wastewater at almost all the levels of dilutions of 20,40, 60, and 80 and original wastewater. CW showed the maximum removal efficiency for $\mathrm{Ni}$ and $\mathrm{Cd}$ as depicted in Figures 9 and 10 , respectively. $\mathrm{CW}$ posttreatment of $\mathrm{Pb}$ was not satisfactory in the reduction of its concentration. Using the San Joaquin Marsh constructed wetlands, the removal efficiencies for four heavy metal elements $\mathrm{Cd}, \mathrm{Cu}, \mathrm{Pb}$, and $\mathrm{Zn}$ were evaluated. It was found that the effluent metal concentrations were not substantially lower than the influent. The removal efficiencies of $23.9 \%, 10.6 \%$, and $17.6 \%$ were found for $\mathrm{Cd}, \mathrm{Cu}$, and $\mathrm{Zn}$, respectively. No significant reduction was observed for concentrations of $\mathrm{Pb}$ [42].

Metal and metalloid removal in constructed wetlands from industrial waste water have been investigated [43]. The removal of metals and metalloids from contaminated waters was investigated in constructed wetlands. Metal removal rates in wetlands depend on the type of element $(\mathrm{Hg}>\mathrm{Mn}>\mathrm{Fe}$ $1 / 4 \mathrm{Cd}>\mathrm{Pb} 1 / 4 \mathrm{Cr}>\mathrm{Zn} 1 / 4 \mathrm{Cu}>\mathrm{Al}>\mathrm{Ni}>\mathrm{As}$ ), their ionic forms, substrate conditions, season, and plant species. Standardized procedures and data are lacking for efficiently comparing properties of plants and substrates. The study depicted the relative treatment efficiency index (RTEI) to quantify treatment impacts on metal removal in constructed wetlands.

Various mechanisms, including sedimentation, filtration, chemical precipitation, adsorption, microbial interactions, and uptake by vegetation, have been attributed with the removal of metal within CW. Specifically, the major processes that are responsible for metal removal in CW are binding to sediments and soils, precipitation as insoluble salts, and uptake by plants and bacteria [44]. In CW, substrate interactions remove most metals from contaminated water [45]. The anoxic condition of wetland soil helps create an environment for immobilization of heavy metals in the highly reduced sulfite or metallic form [46]. Wetland plants adsorb and accumulate metals in tissues, which can play an important role in CW pollutant treatment efficiency [47]. Phytoremediation, using vegetation to remove, detoxify, or stabilize heavy metal pollutants, is an accepted tool for cleaning polluted soils and waters [48]. Research has also shown that metal storage in the sediment is influenced by vegetation. Concentrations of metals were significantly higher in the vegetated sediments than in the nonvegetated sediments [49]. 


\section{Conclusion}

This paper presented the evaluation results on removal efficiencies for COD, BOD, nitrates, phosphates, TS, and heavy metals $(\mathrm{Cd}, \mathrm{Ni}$, and $\mathrm{Pb})$ in $\mathrm{ABR}$ and posttreated by a lab scale Arundo donax based CW. It was clearly observed that posttreatment accomplished tremendous removal of the COD, BOD, TS Ni, and Cd. The efficiency of both the treatment systems was not too much satisfactory for $\mathrm{Pb}$ removal. Because of the positive effects of vegetation on metal removal efficiency, CWs containing $A$. donax is recommended for HIE combined wastewater treatment.

\section{Conflict of Interests}

The authors have neither any conflict of interests nor financial gain from the present paper.

\section{References}

[1] Q. Mahmood, A. Pervez, B. S. Zeb et al., "Natural treatment systems as sustainable ecotechnologies for the developing countries," Biomed Research International, vol. 2013, Article ID 796373, 19 pages, 2013.

[2] B. S. Zeb, Q. Mahmood, and A. Pervez, "Characteristics and performance of anaerobic wastewater treatment (a review)," Journal of Chemical Society of Pakistan, vol. 35, pp. 217-232, 2013.

[3] A. K. Mungray, Z. V. P. Murthy, and A. J. Tirpude, "Post treatment of up-flow anaerobic sludge blanket based sewage treatment plant effluents: a review," Desalination and Water Treatment, vol. 22, no. 1-3, pp. 220-237, 2010.

[4] A. C. van Haandel and G. Lettinga, Anaerobic Sewage Treatment, a Practical Guide for Regions with a Hot Climate, John Wiley \& Sons, New York, NY, USA, 1994.

[5] C. Y. Gomec, "High-rate anaerobic treatment of domestic wastewater at ambient operating temperatures: a review on benefits and drawbacks," Journal of Environmental Science and Health A, vol. 45, no. 10, pp. 1169-1184, 2010.

[6] A. A. Khan, R. Z. Gaur, V. K. Tyagi et al., "Sustainable options of post treatment of UASB effluent treating sewage: a review," Resources, Conservation and Recycling, vol. 55, no. 12, pp. 12321251, 2011.

[7] J. Y. Ji, Y. J. Xing, Z. T. Ma, M. Zhang, and P. Zheng, "Acute toxicity of pharmaceutical wastewaters containing antibiotics to anaerobic digestion treatment," Chemosphere, vol. 91, pp. 10941098, 2013.

[8] B. Lew, M. Belavski, S. Admon, S. Tarre, and M. Green, “Temperature effect on UASB reactor operation for domestic wastewater treatment in temperate climate regions," Water Science and Technology, vol. 48, no. 3, pp. 25-30, 2003.

[9] G. Lettinga, A. F. M. van Velsen, S. W. Hobma, W. D. Zecuw, and A. Klapwijk, "Use of the upflow sludge blanket (USB) reactor concept for biological wastewater treatment, especially for anaerobic treatment," Biotechnolgy and Bioengineering, vol. 22, pp. 699-734, 1980.

[10] G. Lettinga, A. de Man, A. R. M. van der Last et al., "Anaerobic treatment of domestic sewage and wastewater," Water Science and Technology, vol. 27, no. 9, pp. 67-73, 1993.

[11] L. Seghezzo, R. G. Guerra, S. M. González et al., "Removal efficiency and methanogenic activity profiles in a pilot-scale
UASB reactor treating settled sewage at moderate temperatures," Water Science and Technology, vol. 45, no. 10, pp. 243248, 2002.

[12] M. vonSperling and C. A. de Lemos Chernicharo, "Wastewater treatment in warm climates," Water 21, pp. 17-20, 2006.

[13] G. Lettinga, “Towards feasible and sustainable environmental protection for all," Aquatic Ecosystem Health and Management, vol. 11, no. 1, pp. 116-124, 2008.

[14] A. Schellinkhout and C. J. Collazos, "Full-scale application of the UASB technology for sewage treatment," Water Science and Technology, vol. 25, no. 7, pp. 159-166, 1992.

[15] J. T. de Sousa and E. Foresti, "Domestic sewage treatment in an upflow anaerobic sludge blanket-sequencing batch reactor system," Water Science and Technology, vol. 33, no. 3, pp. 73-84, 1996.

[16] A. A. Khan, Post treatment of ABR effluent: aeration and Variant of ASP [Ph.D. thesis], IIT Roorkee, Uttarakhand, India, 2012.

[17] A. A. Khan, R. Z. Gaur, B. Lew, I. Mehrotra, and A. A. Kazmi, "Effect of aeration on the quality of effluent from UASB reactor treating sewage," Journal of Environmental Engineering, vol. 137, no. 6, pp. 464-471, 2011.

[18] M. A. El-Khateeb and A. Z. El Bahrawy, "Extensive post treatment using constructed wetland," Life Science Journal, vol. 10, pp. 560-568, 2013.

[19] W. Verstraete and P. Vandevivere, "New and broader applications of anaerobic digestion," Critical Reviews in Environmental Science and Technology, vol. 29, no. 2, pp. 151-173, 1999.

[20] N. Sato, T. Okubo, T. Onodera, A. Ohashi, and H. Harada, "Prospects for a self-sustainable sewage treatment system: a case study on full-scale UASB system in India's Yamuna River Basin," Journal of Environmental Management, vol. 80, no. 3, pp. 198207, 2006.

[21] A. K. Mungray and P. Kumar, "Anionic surfactants in treated sewage and sludges: risk assessment to aquatic and terrestrial environments," Bioresource Technology, vol. 99, no. 8, pp. 29192929, 2008.

[22] M. A. El-Khateeb and F. A. El-Gohary, "Combining ABR Technology and Wetland for Domestic Wastewater Reclamation and Reuse," Water Supply, vol. 3, 2003.

[23] B. Hegazy, M. A. El-Khateeb, A. E.-A. Amira, and M. M. Kamel, "Low-cost wastewater treatment technology," Journal of Applied Sciences, vol. 7, no. 6, pp. 815-819, 2007.

[24] M. A. El-Khateeb, A. Z. Al-Herrawy, M. M. Kamel, and F. A. El-Gohary, "Use of wetlands as post-treatment of anaerobically treated effluent," Desalination, vol. 245, no. 1-3, pp. 50-59, 2009.

[25] V. Mudgal, N. Madaan, and A. Mudgal, "Heavy metals in plants, phytoremediation: plants used to remediate heavy metal pollution," Agriculture and Biology Journal of North America, vol. 1, pp. 40-46, 2010.

[26] N. Korboulewsky, R. Wang, and V. Baldy, "Purification processes involved in sludge treatment by a vertical flow wetland system: focus on the role of the substrate and plants on $\mathrm{N}$ and $\mathrm{P}$ removal," Bioresource Technology, vol. 105, pp. 9-14, 2012.

[27] C. Wendland, J. Behrendt, T. A. Elmitwalli et al., "ABR reactor followed by constructed wetland and UV radiation as an appropriate technology for municipal wastewater treatment in Mediterranean countries," in Proceedings of the 7th Specialized Conference on Small Water and Wastewater Systems in Mexico, 2006.

[28] P. Worrall, K. J. Peberdy, and M. C. Millett, "Constructed wetlands and nature conservation," Water Science and Technology, vol. 35, no. 5, pp. 205-213, 1997. 
[29] C. M. Kao and M. J. Wu, "Control of non-point source pollution by a natural wetland," Water Science and Technology, vol. 43, no. 5, pp. 169-174, 2001.

[30] J. García, P. Aguirre, R. Mujeriego, Y. Huang, L. Ortiz, and J. M. Bayona, "Initial contaminant removal performance factors in horizontal flow reed beds used for treating urban wastewater," Water Research, vol. 38, no. 7, pp. 1669-1678, 2004.

[31] M. von Sperling and L. C. A. M. Mascarenhas, "Performance of very shallow ponds treating effluents from UASB reactors," Water Science and Technology, vol. 51, no. 12, pp. 83-90, 2005.

[32] M. von Sperling, R. K. X. Bastos, and M. T. Kato, "Removal of E. coli and helminth eggs in ABR: polishing pond systems in Brazil," Water Science and Technology, vol. 51, no. 12, pp. 91-97, 2005.

[33] C. A. L. Chernicharo, "Post-treatment options for the anaerobic treatment of domestic wastewater," Reviews in Environmental Science and Biotechnology, vol. 5, no. 1, pp. 73-92, 2006.

[34] American Public Health Association, Standard Methods for the Examination of Water and Wastewater, APHA, New York, NY, USA, 21st edition, 2005.

[35] A. Mudhoo, R. M. Pravish, and M. Romeela, "Effects of microwave heating on biogas production, chemical oxygen demand and volatile solids solubilization of food residues. world academy of science," Engineering and Technology, vol. 69, pp. 805-810, 2012.

[36] M. Sarioglu, S. Akkoyun, and T. Bisgin, "Inhibition effects of heavy metals (copper, nickel, zinc, lead) on anaerobic sludge," Desalination and Water Treatment, vol. 23, no. 1-3, pp. 55-60, 2010.

[37] K. J. Prakash, V. K. Tyagi, A. A. Kazmi, and A. Kumar, "Posttreatment of UASB reactor effluent by coagulation and flocculation process," Environmental Progress, vol. 26, no. 2, pp. 164-168, 2007.

[38] I. Machdar, Y. Sekiguchi, H. Sumino, A. Ohashi, and H. Harada, "Combination of a UASB reactor and a curtain type DHS (downflow hanging sponge) reactor as a cost-effective sewage treatment system for developing countries," Water Science and Technology, vol. 42, no. 3-4, pp. 83-88, 2000.

[39] T. V. Kumar, A. A. Khan, A. A. Kazmi, I. Mehrotra, and A. K. Chopra, "Slow sand filtration of UASB reactor effluent: a promising post treatment technique," Desalination, vol. 249, no. 2, pp. 571-576, 2009.

[40] A. M. Gower, Water Quality in Catchment Ecosystems, John Wiley \& Sons, New York, NY, USA, 1980.

[41] C. S. C. Calheiros, A. F. Duque, A. Moura et al., "Substrate effect on bacterial communities from constructed wetlands planted with Typha latifolia treating industrial wastewater," Ecological Engineering, vol. 35, no. 5, pp. 744-753, 2009.

[42] S. Hafeznezami, J.-L. Kim, and J. Redman, "Evaluating removal efficiency of heavy metals in constructed wetlands," Journal of Environmental Engineering, vol. 138, no. 4, pp. 475-482, 2012.

[43] L. Marchand, M. Mench, D. L. Jacob, and M. L. Otte, "Metal and metalloid removal in constructed wetlands, with emphasis on the importance of plants and standardized measurements: a review," Environmental Pollution, vol. 158, no. 12, pp. 3447-3461, 2010.

[44] R. H. Kadlec and S. D. Wallace, Treatment Wetlands, Taylor \& Francis Group, Boca Raton, Fla, USA, 2nd edition, 2008.

[45] D. J. Walker and S. Hurl, "The reduction of heavy metals in a stormwater wetland," Ecological Engineering, vol. 18, no. 4, pp. 407-414, 2002.
[46] R. P. Gambrell, "Trace and toxic metals in wetlands-a review," Journal of Environmental Quality, vol. 23, no. 5, pp. 883-891, 1994.

[47] H. Brix, "Functions of macrophytes in constructed wetlands," Water Science and Technology, vol. 29, no. 4, pp. 71-78, 1994.

[48] S. Cheng, W. Grosse, F. Karrenbrock, and M. Thoennessen, "Efficiency of constructed wetlands in decontamination of water polluted by heavy metals," Ecological Engineering, vol. 18, no. 3, pp. 317-325, 2002.

[49] J. H. Choi, S. S. Park, and P. R. Jaffé, "The effect of emergent macrophytes on the dynamics of sulfur species and trace metals in wetland sediments," Environmental Pollution, vol. 140, no. 2, pp. 286-293, 2006. 

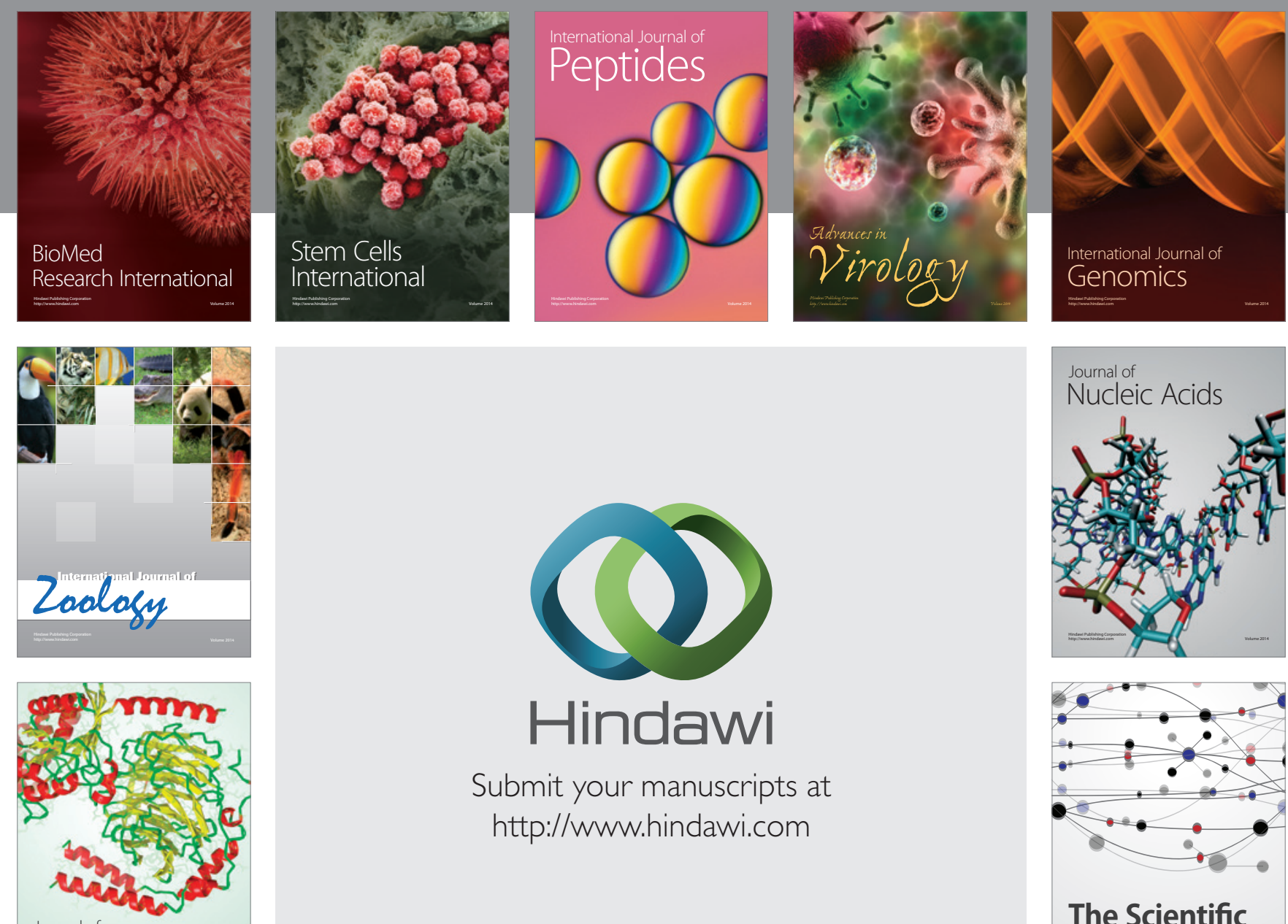

Submit your manuscripts at

http://www.hindawi.com

Journal of
Signal Transduction
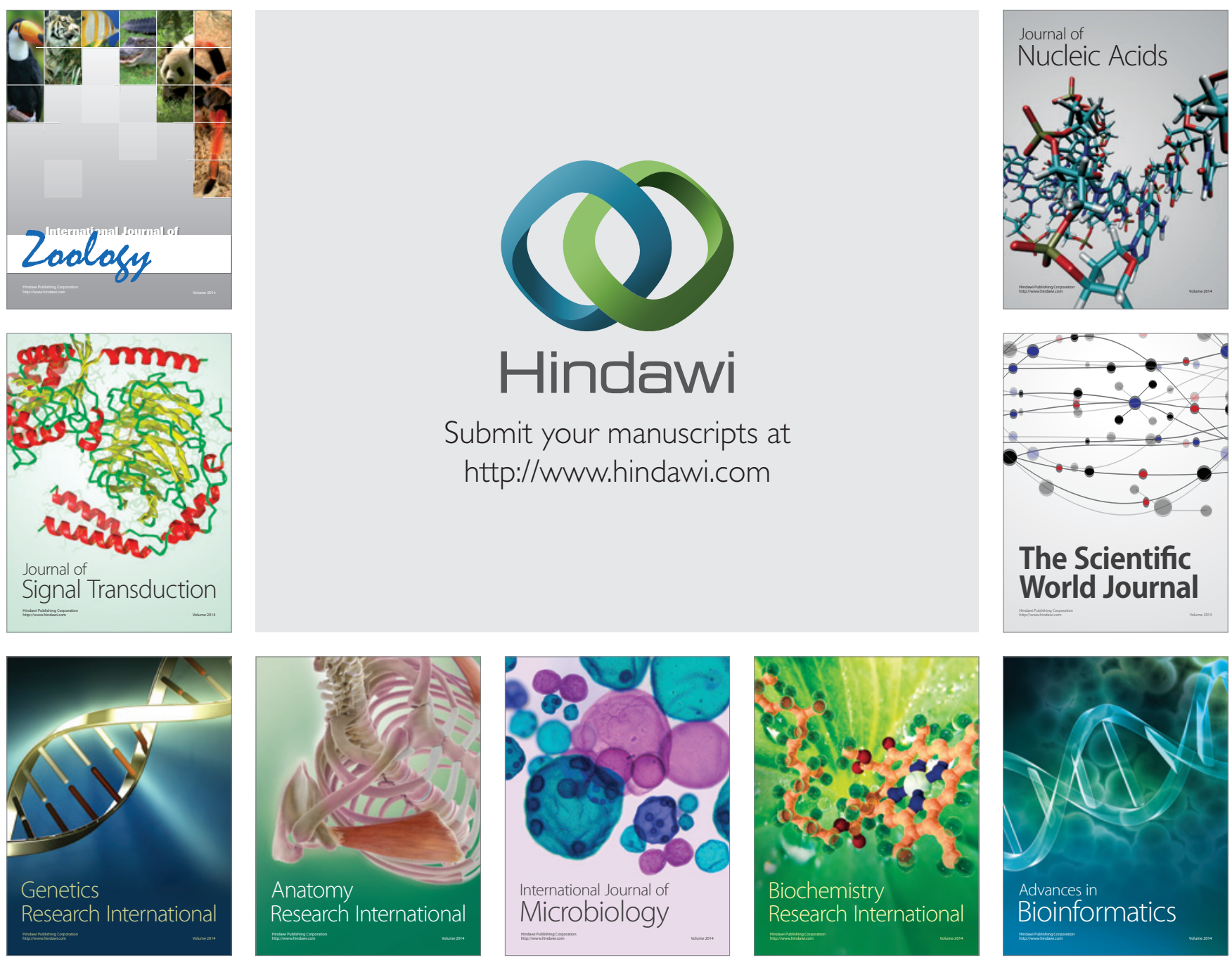

The Scientific World Journal
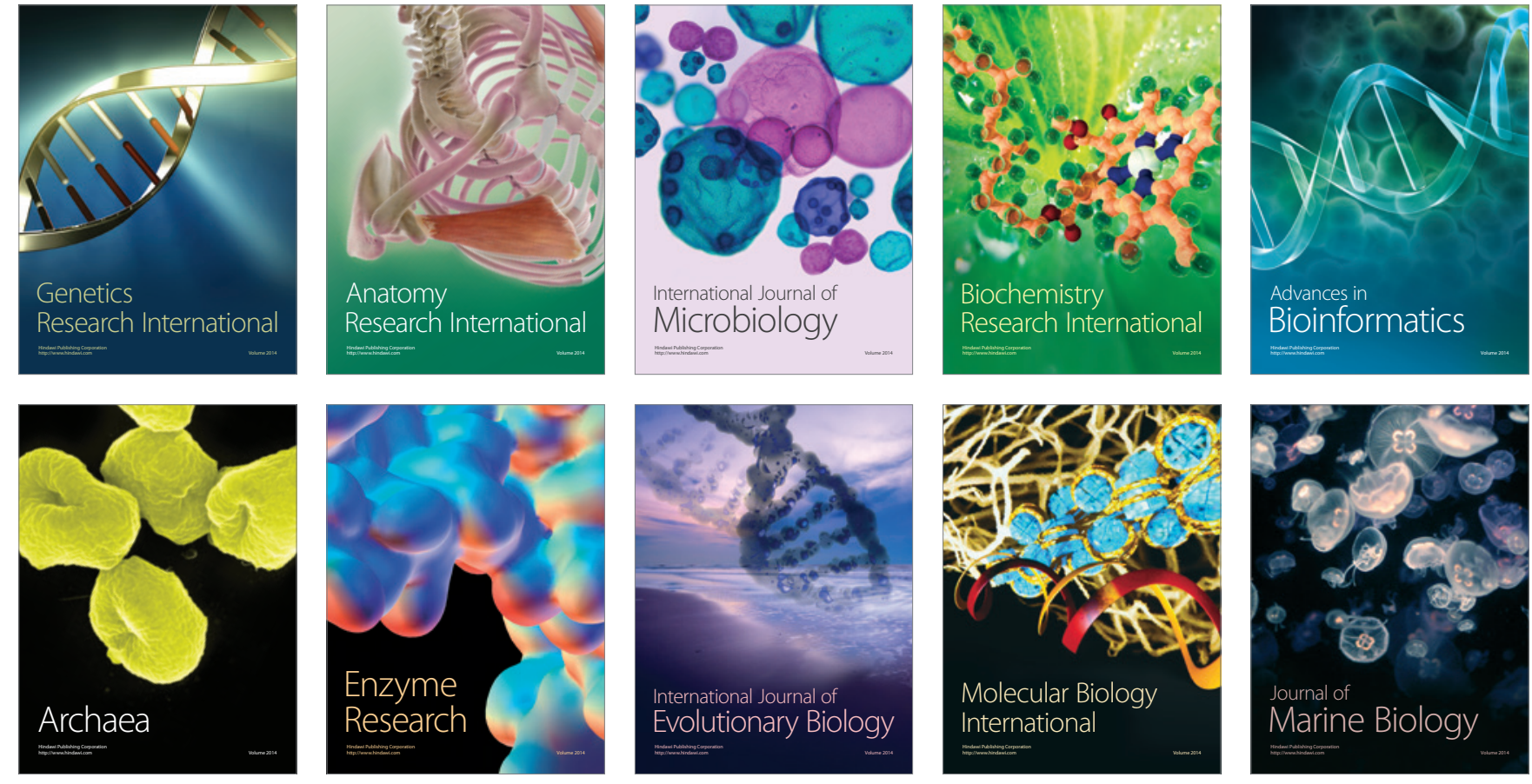